\title{
Pengaruh Toilet training Media Balloon dengan Tehnik Modelling Terhadap Bina Diri (BAB \& BAK) Anak Down syndrome
}

\author{
Radina Radina \\ ${ }^{1}$ Universitas Lambung Mangkurat, Indonesia \\ Email: radina1513@gmail.com
}

\section{INFORMASI ARTIKEL}

Terkirim 22-Mei-2020

Revisi 29-Sep-2020

Diterima 29-Nov-2020

\section{Kata kunci:}

Modeling, Toilet training,

Down syndrome

\begin{abstract}
ABSTRAK
Pada penelitian ini yang menjadi sasaran subjek yang akan diteliti adalah anak dengan hambatan intelektual (down syndrome). Tujuan penelitian mengembangkan tehnik modelling pembelajaran keterampilan bina diri pada anak down syndrome dengan toilet training sesuai dengan karakteristik dan kebutuhan siswa down syndrome. Dalam membelajarkan toilet training pada down syndrome diantaranya dapat menggunakan media balloon. Jenis penelitian menggunakan pendekatan kuantitatif dengan jenis penelitian SSR. Teknik pengumpulan data observasi langsung, dokumentasi serta wawancara. Metode pengumpulan data analisis kemampuan toilet training. Hasil dianalisis meliputi jumlah pengamatan dalam kondisi awal sebanyak $8 \mathrm{x}$ dan kondisi intervensi sebanyak 52 sesi/minggu. Hasil penelitian ditujukan untuk analisis data dalam kondisi dan analisis data antara kondisi menunjukkan perubahan kemampuan pelatihan toilet $\mathrm{X}$ ke arah yang lebih baik, terbukti dari data yang diperoleh selama kondisi baseline, hanya $37,5 \%$ sedangkan data yang diperoleh selama kondisi intervensi pada 50 hingga 52 sesi kemampuan anak untuk pelatihan toilet adalah $100 \%$.
\end{abstract}

\section{Pendahuluan}

Setiap anak memiliki masa perkembangan yang berbeda-beda. Dalam hal ini tidak menutup kemungkinan terjadinya gangguan. Gangguan serius yang sering terjadi pada masa tumbuh kembang anak adalah salah satunya gangguan bicara, autisme, lambat belajar, dan retardasi mental. Retardasi mental atau biasa disebut tunagrahita atau down syndrome adalah kondisi seseorang yang memiliki kecerdasan dibawah rata-rata. Seseorang dapat dikatakan retardasi mental atau tunagrahita, jika memiliki tingkat kecerdasan di bawah rat-rata, sehingga untuk menyelesaikan tugas perkembangannya memerlukan bantuan atau layanan secara spesifik, termasuk dalam program pendidikannya (Affendi, 2006).

Kegiatan toilet training diajarkan pada anak ketika umur balita begitupun kepada anak dengan hambatan intelektual (down syndrome). Namun pada kenyataannya masih banyak siswa dengan kecerdasan dibawah rata-rata yang masih belum bisa melakukan toilet training dalam program kebersihan diri seperti, belum dapat menggunakan kamar mandi dengan baik. Masalah yang sering dialami oleh siswa down syndrome adalah yang belum bisa mencebok saat sudah selesai pada saat sedang BAK/BAB, pintu kamar mandi tidak di tutup. Selain itu siswa down syndrome tidak menjaga kebersihan sekitar kloset. Sulitnya siswa down syndrome dalam memahami materi menyebabkan guru harus berulang-ulang dalam memberikan instruksi.

Bagi anak down syndrome, pembelajaran mengenai bina diri memerlukan waktu lebih lama. 
Pasalnya, mereka memiliki keterbatasan fisik dan kognitif 50\% dari anak-anak dengan down syndrome memiliki IQ antara 51 hingga 70, menunjukan rendah skor pada psikomotor, adaptif dan kemampuan sosial di segala usia dibandingkan dengan anak normal dan ini juga terlihat dalam kaitannya dengan kemampuan makan, sosialisasi, toilet training dan tidur (Bhatia, Kabra, and Sapra, dalam Mariana, 2013).

Walaupun kelihatannya sederhana, keterampilan ini bukan sesuatu yang mudah bagi anak down syndrome untuk dikuasai. Mereka yang mampu berbicara cukup baik, mengikuti pelajaran, dan berinteraksi sederhana dengan teman-temannya bahkan tidak dengan sendirinya berhasil dalam toilet training bila tidak dilatih sejak usia dini. Mungkin karena dianggap bukan hal penting atau akibat ketidaktahuan tentang cara melatihnya, cukup banyak orang tua yang baru sadar bahwa anaknya belum mandiri dalam kegiatan BAB dan BAK (Ginanjar dalam Mariana, 2013).

Program keterampilan bina diri tersebut terdiri dari tujuh aspek yang pertama keterampilan merawat diri, mengurus diri, menolong diri kemudian keterampilan berkomunikasi, bersosialisasi, keterampilan hidup sehari-hari dalam mengisi waktu luang (Anggraini, 2018). Dari ketujuh ruang lingkup bina diri yang telah disebutkan keterampilan bina diri yang dimaksud dalam penelitian ini adalah keterampilan dalam mengurus diri. Dimana keterampilan mengurus diri adalah pelajaran yang berkaitan dengan kegiatan yang biasa dilakukan utuk mengatasi berbagai mesalah dalam kehidupan sehari-

hari. Aktifitas yang dimaksud adalah berbagai pekerjaan sehari-hari dirumah yaitu mandi, makan, berpakaian, kebersihan BAK dan BAB (Anggraini, 2018).

Fungsi BAK pada anak-anak dengan down syndrome dianggap berkorelasi dengan fungsi kognitifnya secara keseluruhan, meskipun kemampuan menilai apa yang disebut berkemih (BAK) abnormal dibatasi oleh kurangnya data normatif pada tingkat kontinuitas pada anak-anak dengan down syndrome. Peneliti berusaha untuk memperluas basis pengetahuan tentang pola berkemih normal dan abnormal pada anak-anak dengan down syndrome, membandingkan data yang menarik dengan populasi kontrol. Mereka berhipotesis bahwa anak-anak dengan down syndrome mengalami keterlambatan dalam mencapai kontrol kemauan urin dan mengalami lebih banyak gejala disfungsi berkemih daripada kontrol..Oleh karena itu, dalam memberikan materi pembelajaran kepada siswa tunagrahita atau down syndrome sebaiknya menggunakan media yang lebih variatif dan menarik (Powers et al., 2015).

Pengadaan dan penggunaan media dalam pembelajaran sangat mempermudah siswa dalam memahami materi yang sedang dipelajari, dengan menggunakan media dapat meningkatkan motivasi anak dan menghilangkan rasa bosan pada diri anak. Dan selain itu informasi yang diberikan melalui analisis tugas disertai demontrasi oleh guru lebih tajam tersimpan dalam memori jangka panjang anak. Disamping itu media lebih efesien dalam penggunaanya berdasarkan hasil penelitian "Media Tiga Dimensi Terhadap Kemampuan Bina Diri Anak Tunagrahita Ringan" menunjukkan bahwa setelah diberikan media model tiga dimensi, keterampilan bina diri tunagrahita ringan mengalami peningkatan. Media pembelajaran adalah segala alat bantu yang dapat membantu siswa agar tujuan pembelajaran tersampaikan secara rinci dan jelas (Djamarah dalam Dian, 2019). Dalam hal penggunaan media pembelajaran harus disesuaikan dengan kebutuhan siswa, agar tercapainya pembelajaran komunikasi dan interaksi antar siswa dan guru (Sudjana dalam Dian, 2019). Adapun media yang digunakan dapat berupa gambar seri, kartu bergambar yang menarik perhatian anak maupun menggunakan buku panduan. Pengembangan buku panduan ini merujuk pada karya Indrawati (2014) yang menyebutkan bahwa buku panduan efektif digunakan dalam proses pembelajaran. Buku panduan pembelajaran toilet training ini merupakan inovasi baru yang dapat dijadikan media pembelajaran dalam proses pembelajaran bina diri khususnya toilet training. Buku panduan ini dibuat 
sejalan dengan media gambar yang dikembangkan menjadi buku panduan. Sejalan dengan penelitian karya Azizah (2014) yang menjelaskan bahwa media gambar juga berpengaruh terhadap kemampuan siswa dalam belajar.

Buku panduan pembelajaran toilet training dirancang merujuk pada pendekatan analisis tugas. Kustawan dan Yanti (2014) mengemukakan analisis tugas adalah upaya merincikan dari satu keterampilan menjadi langkah-langkah kecil yang memungkinkan peserta didik mudah dalam pelaksanaanya. Sementara itu, untuk mengajarkan anak tunagrahita sedang dalam melakukan toilet training adalah dengan pendekatan analisis tugas oleh Panjaitan, dkk (2013) yang menunjukan bahwa adanya peningkatan setelah diberikan perlakuan melalui analisis tugas kemampuan toilet training dalam melakukan buang air kecil anak tunagrahita sedang sebanyak 52,88\%. Analisis tugas dapat membantu siswa dalam mempelajari setiap langkah kecil dari suatu proses, sehingga siswa tersebut akan mampu melakukannya sampai tugas yang cukup rumit.

Pendapat (Pratiwi \& Kustiawan, 2017) juga mengembangkan buku panduannya dengan judul "Pembelajaran Toilet training bagi Siswa Tunagrahita". Dari hasil validasi, uji coba individu dan uji coba kelompok dapat simpulkan bahwa buku panduan pembelajaran toilet training bagi siswa tunagrahita layak dan efektif digunakan dalam proses pembelajaran.

Hasil penelitian yang mendukung penelitian saya ialah oleh (Mariana, 2013) dengan judul "Toilet training Pada Anak Down syndrome". Adapun hal yang terungkap dalam penelitian ini adalah terdapat gambaran mengenai toilet training anak down syndrome, yang meliputi kemampuan toilet training subyek, pelaksanaannya, serta faktor pendukung dan penghambat keberhasilan toilet training subyek tersebut.

Banyak faktor yang mempengaruhi kemampuan bina diri toilet training anak tunagrahita, menurut Eko (2016) diantaranya kesiapan fisik, kesiapan psikologis, kesiapan intelektual, sarana dan prasarana. Suksesnya toilet training dapat dilihat pada ketersediaannya fasilitas dan kesiapan yang ada pada diri anak dan keluarga terutama ibu, seperti kesiapan fisik yaitu kemampuan anak sudah kuat dan mampu. Demikian juga dengan kesiapan psikologis yaitu setiap anak membutuhkan suasana yang nyaman agar anak mampu mengontrol dan konsentrasi dalam melakukan untuk BAB atau BAK. Kesiapan intelektual juga dapat membantu anak memahami dalam proses BAB atau BAK. Dengan adanya Fasilitas yang baik, maka juga akan sangat berpengaruh terhadap perkembangan kemampuan anak, baik di rumah maupun di sekolah. Adapun hasil penelitian oleh (Andriyani et al., 2014) juga terdapat faktor yang berhubungan dengan keberhasilan pelaksanaan toilet training pada anak diantaranya adalah faktor pengetahuan orangtua mengenai toilet training dan faktor lingkungan.

Dalam pelaksanaan bimbingan dan konseling, kebanyakan guru (82\%) memfasilitasi siswa tuna netra untuk berpartisipasi aktif dalam bimbingan dan konseling. Untuk mendorong partisipasi siswa aktif, sebagian besar guru (73\%) menciptakan kondisi yang akan memotivasi dan menarik siswa tuna netra untuk terlibat secara aktif dalam bimbingan dan konseling. Maka dalam pelaksanaan bimbingan bina diri pun guru juga harus memfasilitasi anak down syndrome agar aktif berpatisipasi dalam bimbingan bina diri seperti memberikan motivasi berupa media yang menarik perhatian anak (Yuwono et al., 2017).

Tehnik yang mendukung penelitian saya ambil ialah oleh Utami (2019) dengan judul "Bimbingan kelompok dengan modelling untuk meningkatkan minat bina diri bagi anak penyandang tunagrahita". Penelitian ini menyatakan bahwa dari hasil pelaksanaan yang dilakukan bimbingan dengan teknik modeling mulai mengalami kemajuan dalam hal mau mengikuti ketrampilan sesuai dengan minatnya dan tidak malu dengan kekurangannya. Setelah mengikuti bimbingan kelompok anak tunagrahita menjadi lebih baik dan meningkat dibandingkan sebelumnya.

Penelitian lain yang mendukung oleh Istiqomah (2016) dengan judul "Tehnik Modelling 
terhadap kemampuan toilet training Anak Cerebral Palsy TKLB/D-Dl”. Hasil penelitiannya menunjukkan bahwa adanya pengaruh penggunaan teknik modelling terhadap kemampuan toilet training anak cerebral palsy TKLB-D/D1 YPAC Malang.

Sementara itu, (Putri, 2014) dengan judul "Model Pembelajaran Keterampilan Bina Diri Bagi Anak Usia Dini Tunagrahita". Hasil Penelitian ini menunjukkan bahwa diperoleh kesimpulan beberapa hal, yaitu (1) guru cenderung kurang menguasai materi (2) pemberian bantuan cenderung belum dilaksanakan sesuai dengan langkah-langkah latihan yang ditulis dalam RPP, (3) guru cenderung kurang menumbuhkan motivasi belajar siswa, dalam hal ini kurang memberi pujian, (4) dalam pelaksanaan penilaian, guru cenderung kurang melakukan pencatatan keberhasilan dan kesulitan yang dihadapi siswa tunagrahita sepanjang proses latihan melepas dan mengenakan pakaian, (5) proses pengembangan model pembelajaran keterampilan bina diri diawali dengan analisis kebutuhan dan dilandasi oleh teori belajar dan didukung oleh berbagai teori dan prinsip pembelajaran, dan (6) Penerapan model pembelajaran ini menggunakan prosedur analisis tugas, bimbingan fisik, model, instruksi verbal dan penguatan positif yang dilakukan.

Seseorang dapat dikatakan mampu apabila memiliki kemampuan untuk mengerjakan dan meyelesaikan sesuatu dengan baik. Demikian halnya dengan anak down syndrome dikatakan memiliki kemampuan dalam toilet training apabila yang bersangkutan tersebut mampu melakukan tahapantahapan sebagaimana yang dilakukan oleh orang-orang pada umumnya. Maka dari itu, Toilet training sangat baik dilakukan sejak dini untuk menerapkan kebiasaan yang baik pada anak. Hal ini penting dilakukan untuk melatih kemandirian anak dalam melakukan BAK dan BAB sendiri. Toilet training dapat dikatakan berhasil dengan baik apabila ada kerjasama antara orangtua, guru dan anak.

Berkaitan dengan permasalahan di atas, maka penelitian ini bertujuan untuk membuktikan serta mengembangkan dari beberapa penelitian diatas yaitu dengan menggunakan media yang konkrit apakah ada pengaruh toilet training media balloon dengan tehnik modelling dalam bina diri anak down syndrome dalam membersihkan diri pada saat BAK dan BAB. Dari beberapa contoh penelitian yang dilakukan diatas, terdapat titik singgung yang sama, yaitu mengenai keterampilan bina diri. Akan tetapi fokus dan lokasi penelitian serta media yang digunakan berbeda dengan apa yang dikaji oleh peneliti. Peneliti akan mengkaji penelitian dengan judul "Pengaruh Toilet training Media Balloon Dengan Tehnik Modelling Terhadap Bina Diri Anak Down syndrome”. Tetapi setidaknya hasil-hasil penelitian tersebut akan dijadikan bahan pelajaran dan bahan bandingan untuk memperkaya dan memperdalam penelitian ini. Untuk itu perlu dikembangkan dari jurnal tersebut yaitu menggunakan media balloon dengan tehnik modelling. Media ini memberikan kesan konkrit untuk anak belajar secara langsung dan secara nyata. Kalau hanya dengan media buku panduan menurut saya kurang efektif disertai analisis tugas anak hanya akan bosan melihat gambar-gambar. Oleh karena itu, peneliti mengembangkan pemilihan model, media dan bahan ajar yang menarik disertai analisis tugas dengan tehnik modelling dengan demonstrasi oleh guru agar pelaksanaan toilet training dapat berjalan dengan lancar.

Toilet training akan dapat berhasil dengan baik apabila ada kerjasama antara orangtua dengan anak. Apabila terjalin kerja sama yang baik akan memberikan rasa saling percaya pada orang tua dan anak. Menurut beberapa penelitian, sikap, tingkah laku dan cara berpikir anak kelak setelah ia dewasa akan sangat dipengaruhi pengalamannya pada saat ini. Toilet training sangat penting dalam membentuk karakter anak dan membentuk rasa saling percaya dalam hubungan anak dan orangtua. Dampak orangtua tidak menerapkan toilet training pada anak diantaranya adalah anak menjadi keras kepala dan susah untuk diatur (Hidayat, 2005; 62).

Berdasarkan uraian di atas dapat dikatakan bahwa program keterampilan bina diri bagi anak down syndrome sangat penting. Secara khusus anak down syndrome mengalami hambatan dalam 
kecerdasan maka target kemandiriannya tentu harus dioptimalkan sesuai dengan potensi yang mereka punya untuk memudahkan siswa dengan kecerdasan di bawah rata-rata, karena mengingat rendahnya intelektual yang menyebabkan kesulitan belajar secara mandiri dalam kebersihan diri yang menjadikan siswa bergantung pada orang lain.

\section{Metode}

Penelitian ini menggunakan pendekatan kuantitatifdengan jenis penelitian SSR (Single Subject Research) yang bertujuan untuk memperoleh data dari hasil treatment yang diberikan pada fase intervensi terhadap pengaruh bina diri BAK dan BAK anak down syndrome dengan menggunakan teknik modelling.

\section{Hasil Penelitian}

Pengumpulan data pada penelitian ini dilakukan hampir selama dua bulan. Yaitu 8 hari untuk kondisi baseline dan 52 hari dalam delapan minggu untuk enam kali pertemuan setiap satu minggunya. Berikut adalah deskripsi data hasil analisis visual grafik yang di dapat selama pengamatan pada kondisi baseline dan intervensi.

Kondisi baseline merupakan pengamatan terhadap kemampuan toilet training dalam melakukan buang air kecil sebelum di berikan perlakuan. Data kondisi baseline pada kemampuan toilet training adalah $12,5 \%, 12,5 \%, 12,5 \%, 12,5 \%, 25 \%, 37,5 \%, 37,5 \%$, dan 37,5\%. Pada kondisi baseline ini terlihat rata-rata kestabilan kemampuan toilet training berada pada tingkat 37,5\%.

Kondisi intervensi merupakan pengamatan terhadap kemampuan toilet training setelah di berikan perlakuan. Data kondisi intervensi pada kemampuan toilet training adalah 80,76\%, 84,61\%, $84,61 \%, 88,46 \%, 88,46 \%, 88,46 \%$, dan $100 \%$.

Hasil analisis dalam kondisi pada setiap komponennya dapat dijabarkan sebagai berikut: panjang kondisi penelitian ini adalah pada kondisi baseline 8 dan pada kondisi intervensi 7. Estimasi kecenderungan arah pada kondisi baseline garis menaik dengan keterjalan yang rendah $(+)$ sedangkan pada kondisi intervensi menunjukkan arah kecenderungan menaik dengan cukup terjal dan bervariasi. Kecenderungan stabilitas pada kondisi baseline 0\% dan kondisi intervensi 50\%. Jejak data pada kondisi baseline bervariasi dan akhirnya sama sedangkan kondisi Intervensi (B) data yang diperoleh juga bervariasi dan akhirnya stabil. Level stabilitas dan rentang pada kondisi baseline 12,5\% - 37,5\% sedangkan pada kondisi intervensi 80,76\% - 100\%. Perubahan level pada kondisi baseline 37,5\% $12,5 \%=25 \%(+)$ dan pada kondisi intervensi $100 \%-80,76 \%=19,24 \%(+)$.

Hasil analisis visual grafik antar kondisi yaitu jumlah variabel 1, perubahan kecendrungan arah pada kondisi baseline (A) stabilitas kecenderungan data sedikit menaik dan bervariasi 12,5\% - 37,5\% (+) dengan keterjalan yang rendah. Sedangkan pada kondisi Intervensi (B) stabilitas kecenderungan data menaik sedikit lebih tinggi dan juga bervariasi $80,76 \%-100 \%(+)$ dengan cukup terjal. Perubahan stabilitas tidak stabil ke tidak stabil. Perubahan level $80,76 \%-37,5 \%=43,26 \%(+)$ dan persentase overlap $0 \%$.

Kondisi Baseline menunjukkan bahwa pengamatan pertama sampai pengamatan ke empat anak memperoleh hasil $12,5 \%$ sedangkan pada pengamatan ke lima mengalami kenaikan yaitu $25 \%$. Pengamatan ke enam sampai ke delapan juga mengalami peningkatan yaitu 37,5\%. Kondisi Intervensi menunjukkan bahwa kemampuan anak pada pengamatan ke sembilan yaitu $80,76 \%$ sedangkan pada pengamatan ke sepuluh sampai ke sebelas mengalami peningkatan $84,61 \%$. Pengamatan ke dua belas sampai pengamatan ke empat belas juga mengalami peningkatan $88,46 \%$ dan pengamatan ke lima belas mengalami peningkatan $100 \%$ sehingga data yang di peroleh sudah stabil. 


\section{Pembahasan}

Hasil penelitian yang telah di lakukan pada anak down syndrome pada kegiatan toilet training dalam melakukan BAK dan BAB melalui pendekatan analisis tugas efektif untuk diajarkan pada anak. Hal ini terbukti pada hasil pengamatan pertama yaitu kemampuan toilet training dalam melakukan buang air kecil pada kondisi Baseline (A) tidak stabil karena bisa dilihat pada pengamatan pertama sampai keempat skor yang di dapat anak 12,5\% kemudian pengamatan kelima meningkat 25\% dan pengamatan keenam sampai kedelapan 37,5\% data mendatar. Dari delapan kali pengamatan yang konsisten, rentang data yang diperoleh 37,5\% - 37,5\%. Pada kondisi intervensi (B) kemampuan anak juga tidak stabil karena bisa dilihat jumlah skor yang didapat anak yaitu pengamatan ke sembilan $80,76 \%$, pengamatan sepuluh sampai pengamatan ke sebelas $84,61 \%$, pengamatan ke dua belas sampai pengamatan ke empat belas $88,46 \%$ dan pengamatan ke lima belas $100 \%$. Dari lima puluh dua kali pengamatan dalam delapan minggu dengan enam kali pertemuan setiap minggunya membuktikan bahwa setelah di berikan intervensi melalui pendekatan analisis tugas, ternyata kemampuan toilet training dalam melakukan BAK dan BAB meningkat. Hal ini dibuktikan setelah di analisis menggunakan grafik terdapat kecenderungan arahnya meningkat dengan rentang $80,76 \%-100 \%$.

Kemampuan bina diri toilet training di rumah maupun di sekolah merupakan hal penting bagi anak down syndrome dikarenakan dapat menjadikan kemandirian bagi diri anak. Maka dari itu, mengajarkan toilet training pada anak down syndrome khususnya dalam melakukan buang air kecil menurut Wantah (2007: 49) bahwa toilet training adalah salah satu latihan yang di ajarkan baik pada anak normal maupun pada anak tunagrahita sedang agar mereka tetap nyaman dan bersih. Namun bagi anak normal hal ini tidak semudah yang diperkirakan oleh orang tua, dan orang dewasa lainnya. Hal ini dikarenakan setiap perkembangan anak berbeda-beda. Seperti, kapasitas kecerdasan anak down syndrome yang memiliki IQ dibawah rata-rata (IQ dibawah 70) yang disertai kurangnya kemampuan untuk berperilaku adaptif sesuai dengan usianya, mereka mudah sekali menyerah dalam melakukan tugas dan sangat bergantung pada orang lain termasuk dalam kegiatan bina dirinya.

Untuk mengembangkan kemampuan bina diri toilet training pada anak down syndrome, diperlukan suatu pelatihan khusus dan pentingnya pengetahuan mengenai faktor-faktor yang mempengaruhi kemampuan bina diri toilet training. Selain itu kesulitan-kesulitan yang dialami oleh anak down syndrome dalam kegiatan toilet training dapat menjadikan pertimbangan untuk pemberian program penanganan kesulitan tersebut. Adapun faktor-faktor yang mempengaruhi kemampuan bina diri yaitu salah satunya keberhasilan orang tua dalam memberikan bimbingan toilet training pada anak down syndrome yang lain yaitu:

1. Ketidaksiapan orangtua

a. Tidak mengenal tingkat kesiapan anak dalam berkemih dan defekasi

b. Tidak keinginan untuk meluangkan waktu untuk latihan berkemih dan defekasi pada anak

c. Mengalami konflik tertentu atau stres keluarga yang berarti (Subagyo dalam Trisniati, 2015).

2. Pengetahuan yang kurang

Pada orang tua yang mempunyai tingkat pengetahuan yang baik tentang toilet training akan menetapkan sesuai dengan kemampuan dan kesiapan anak. Sebaliknya untuk para orang tua yang memiliki pengetahuan yang kurang tentang toilet training dalam penerapannya tidak sesuai dengan usia serta kemampuan anak. Hal ini dapat mengakibatkan kecemasan, stres dan muncul rasa marah orang tua, jika melihat anak tidak mampu melakukan toilet training (Notoatmodjo dalam Shalahuddin, 2018).

Pengetahuan tentang toilet training memang sangat penting untuk dimiliki oleh seorang ibu. Hal ini akan berdampak pada penerapan toilet training pada anak. Ibu yang mempunyai tingkat 
pengetahuan yang baik maka berarti mempunyai pemahaman yang baik tentang manfaat dan dampak dari toilet training, sehingga ibu akan memiliki sikap yang positif terhadap konsep toilet training itu sendiri. Sikap merupakan kecenderungan ibu untuk bertindak atau berperilaku (Suryabudhi dalam Pusparini, 2010).

3. Pola asuh yang tidak sesuai

Keterampilan toilet training pada anak down syndrome biasanya disebabkan oleh pola asuh orang tua. Ketika anak berusia balita biasanya keterampilan toilet training sudah dilatih atau dibiasakan. Pola asuh orang tua yang tidak memiliki rasa empati karena merasa tidak tegaan untuk melatih kedisiplinan dalam toilet training turut berpengaruh dalam perkembangan kemampuan toilet training. Kebiasaan untuk selalu menolong dan memanjakan menjadikan anak down syndrome sangat tergantung pada orang tua.

4. Motivasi stimulasi toilet training dari orang tua yang rendah

Orang tua akan mudah menerima dan mendorong seseorang untuk melakukan sesuatu untuk memenuhi keinginan dan kebutuhan tertentu, Dengan motivasi yang baik untuk melakukan stimulasi toilet training, maka keberhasilan toilet training dapat terwujud (Subagyo dalam Andriyani, 2020).

Keadaan lingkungan juga salah satu faktor ekstrinsik dalam menentukan ada tidak atau besar kecilnya motivasi seseorang. Motivasi yang baik untuk melakukan stimulasi toilet training, maka dapat memengaruhi keberhasilan dari toilet training Stimulasi ini dapat dilakukan oleh orang luar, anggota keluarga, atau orang dewasa lain di sekitar anak. (Widayatun 1999 dalam Ningsih (2015). Stimulasi merupakan perangsangan dan latihan-latihan terhadap kepandaian anak yang datangnya dari lingkungan di luar anak. Orangtua sebaiknya menyadari akan pentingnya untuk memberikan stimulasi bagi perkembangan anak (Nursalam, 2005 dalam Frima, 2013).

Latihan BAB atau BAK pada anak sangat memerlukan persiapan dari seorang ibu, baik secara fisik, psikologis, maupun intelektual. Melalui persiapan-persiapan tersebut, anak diharapkan dapat mengontrol kemampuan BAB dan BAK dengan mandiri. Suksesnya toilet training tergantung pada kesiapan anak dan orang tua terutama ibu, seperti kesiapan fisik yaitu kemampuan anak sudah siap dan mampu. Demikian juga dengan kesiapan psikologis yaitu setiap anak membutuhkan suasana yang nyaman dan aman agar anak dapat konsentrasi dalam merangsang untuk BAB dan BAK. Persiapan intelektual juga dapat membantu anak dalam proses BAB dan BAK. Kesiapan-kesiapan tersebut akan menjadikan diri anak selalu mempunyai kemandirian dalam mengontrol khususnya dalam hal BAB atau BAK (Hidayat, 2005).

Kesiapan pada anak untuk melakukan toileting training,juga memerlukan pengetahuan dari orangtua mengenai toileting training, dan pelaksanaan toileting yang baik dan benar pada anak, merupakan suatu domain penting yang perlu orang tua ketahui. Domain tersebut dapat meningkatkan kemampuan toileting training pada anak usia toddler (Kusumaningrum, Natosba, \& Julia, 2011). Keberhasilan perubahan perilaku sangat ditentukan oleh kualitas stimulus yang diberikan pada anak. Untuk membentuk respon tersebut diperlukan stimulus seperti mengajarkan toilet training pada anak adalah dengan menggunakan teknik lisan dan teknik modelling. Teknik lisan yaitu dengan memberikan perintah secara langsung dengan kata-kata baik itu sebelum atau sesudah BAB dan BAK dan teknik modelling berupa memberikan contoh buang air kecil dan buang air besar atau membiasakan buang air kecil dan buang air besar secara benar. Untuk penguat agar toilet training yang berjalan secara optimal maka perlu menyiapkan peralatan yang dibutuhkan dan memberikan selamat atau hadiah jika anak mampu menyelesaikan dengan baik (Maulana, 2009).

Hasil Penelitian (Istiqomah, 2016:7) bahwa ada pengaruh penggunaan teknik modelling terhadap kemampuan toilet training pada anak cerebral palsy yang memberikan perubahan positif dari 
sebelum dan sesudah diberikan intervensi. Selain pemberian intervensi dengan teknik modelling, dimana orang tua juga membiasakan anak dalam kegiatan toilet training. Melihat adanya kesiapan orang tua dalam memberikan pendidikan toilet training untuk anak di rumah, hal ini dapat dilihat dari kemauan orang tua meluangkan waktu untuk melatihan anak down syndrome toilet training.

Pentingnya peran seseorang serta orang tua dalam memberikan stimulus, untuk membentuk respon anak down syndrome agar menunjukkan kemajuan dalam toilet training melalui reinforcement sesuai dengan pernyataan Ginanjar (2008) dalam penelitian Frima (2013) tentang manfaat dari reinforcement positif bahwa anak yang berhasil maka ia akan termotivasi untuk melakukan hal yang sama di hari berikutnya sehingga tanpa sadar akan menjadikannya sebagai suatu perilaku yang bersifat lebih menetap. Terdapat beberapa budaya, termasuk Amerika Utara, tentang keberhasilan dalam melakukan toilet training pada anak dianggap sebagai langkah besar pengembangan diri dalam hal kemandirian anak (Lang, 2008).

Hasil penelitian yang dilakukan oleh Onen, Aksoy, Tasar dan Bilge (2012) dapat disimpulkan bahwa inisiasi toilet training dapat disebabkan oleh tingkat ekonomi keluarga, ukuran keluarga, serta status tempat tinggal antara kota dan desa. Terdapat banyak faktor yang dapat mempengaruhi toilet training pada anak diantaranya tingkat pendidikan ibu, sosial dan budaya, tingkat pendapatan keluarga, usia, metode yang digunakan, tempat, jenis toilet, pengetahuan, psikologis anak, status, dan gender.

Dalam penelitian (Mrad et al., 2018) tidak ada faktor khusus untuk pelatihan toilet di anak-anak dengan down syndrome. Hasil penelitian $87,1 \%$ dan $88,2 \%$ orang tua dari anak-anak dengan down syndrome menggunakan pendekatan yang berorientasi pada anak dan kursi toilet untuk pelatihan toilet, mirip dengan mereka yang ada di CG. Dalam penelitian ini, orang tua memberitahukan bahwa pendekatan yang digunakan yang berorientasi pada anak, mengidentifikasi hanya beberapa tanda-tanda kesiapan, yang mungkin telah menentukan awal untuk memulai proses pelatihan toilet. Lebih lanjut, tidak ada hubungan yang diamati antara usia pelatihan toilet dan penggunaan kursi toilet, seperti ditemukan oleh Tarhan et al. yang menggambarkan bahwa anak-anak yang menggunakan peralatan dapat menyelesaikan pelatihan toilet mereka di usia lebih muda.

Toilet training perlu dilakukan oleh anak selama anak berada dalam tahap perkembangan yang optimal untuk menghindari adanya efek seperti inkontinensia dan infeksi saluran kemih (ISK) (Wu, 2013). Dampak yang paling umum terjadi dalam kegagalan toilet training diantaranya adalah adanya perlakuan atau aturan yang ketat dari orangtua kepada anaknya dapat mengganggu kepribadian anak dan cenderung bersikap keras kepala, seperti orang tua yang sering memarahi anaknya pada saat BAB dan BAK atau bahkan melarang anak untuk BAB atau BAK saat dalam bepergian. Selain itu, apabila orang tua yang santai memberikan aturan dalam toilet training, maka anak dapat mengalami kepribadian ekspresif, seperti anak menjadi lebih tegaan, ceroboh, suka membuat masalah, emosional, dan semena-men dalam melakukan kegiatan sehari-hari (Hidayat, 2005). Selain itu, apabila dilakukan toilet training pada usia yang tidak tepat dapat menimbulkan beberapa masalah yang dialami anak yaitu seperti sembelit, menolak toileting, disfungsi berkemih, infeksi saluran kemih, dan enuresis (Hooman et al., 2013).

Toilet training merupakan salah satu bagian dari kegiatan bina diri yang penting untuk diajarkan kepada anak khususnya anak down syndrome kegiatannya seperti, mengurus diri yang apabila diuraikan menjadi komponen-komponen yang lebih kecil meliputi membuka pintu WC, melepas celana luar dan dalam, duduk atau jongkok di atas kloset, kemudian barulah BAK dan BAB, mengambil air dengan gayung, membersihkan diri dengan air, menyiram kloset, mencuci tangan, memakai celana dalam dan luar dan membuka pintu WC. Rangkaian kegiatan dalam toilet training tentu tidak mudah untuk dilakukan pada anak down syndrome. Hal ini dikarenakan anak down 
syndrome mengalami permasalahan motorik, sensorik, kognitif, dan komunikasi yang kompleks, sehingga berdampak pada kesulitan toilet trainingnya. Kemampuan toilet training pada anak autis tentunya tidak sama dengan anak normal. Bagi umumnya anak normal dengan kemampuan yang sempurna secara kognitif maupun motorik, kegiatan sehari-hari dapat dilatih sejak dini. Namun, tidak demikian dengan anak down syndrome, adanya gangguan yang kompleks menyebabkan anak mengalami beberapa kesulitan dalam melakukan kegiatan toilet training sehingga dalam pelaksanannya tidak semudah dan secepat anak pada umumnya. Keterbatasan komunikasi dan kognitif yang dimiliki anak autis tersebut memerlukan metode, teknik, media, kesabaran dan waktu yang lebih lama supaya anak mampu melakukan kegiatan toilet training dengan baik (Khuriyati, 2014).

Faktor lingkungan sangat penting bagi kehidupan manusia karena lingkungan merupakan tempat hidup manusia, tumbuh dan berkembang, serta lingkungan juga memberikan sumber-sumber penghidupan manusia (Herimanto, 2012) Toilet training yang dilakukan di rumah diperlukan lingkungan yang aman, nyaman, dan yang memiliki estetika (Hoffnung dkk, 2010 dalam Fernandez, 2014).

Dalam penelitian ini menyatakan bahwa faktor lingkungan akan berpengaruh terhadap toilet training anak karena memberikan suasana yang lebih aman, nyaman, dan memiliki estetika, sehingga penelitian akan lebih baik dilakukan di rumah.

Hasil studi retrospektif kasus kontrol yang dilakukan oleh (Kiddoo, 2012) menunjukkan bahwa anak-anak yang selalu diberi hukuman oleh ibunya pada saat melakukan kesalahan dalam toilet training anak dapat mengalami gejala inkontinensia atau ISK. Sedangkan pada anak yang mendapatkan motivasi dari ibunya pada saat melakukan toilet training anak dapat mengalami genjala inkontinensia dan ISK yang lebih rendah. Bentuk hukuman pada saat toilet training juga menimbulkan bahaya karena anak akan belajar perilaku agresif dalam mengatasi rasa marah (Rudolph \& Hoffman, 2006). Sementara itu, anak-anak yang selalu diberikan reinforcement positif oleh ibunya maka anak akan semakin termotivasi untuk melakukan toilet training.

Dalam penelitian ini menyatakan bahwa penelitian toilet training dalam bentuk tehnik hukuman akan berdampak pada psikologis anak. Contohnya, trauma, stress dan efek kejeraan pada anak sehingga anak tidak ingin lagi mengikuti toilet training. Lebih lanjut oleh penelitian Renny Panjaitan, Irdamurni dan Kasiyati (2013) dengan judul "Meningkatkan Kemampuan Toilet training Melalui Analisis Tugas Pada Anak Tunagrahita Sedang". Hasil penelitiannya menunjukkan adanya peningkatan kemampuan toilet training pada anak tunagrahita dalam melakukan buang air kecil sebanyak $52,88 \%$.

Dapat disimpulkan bahwa terdapat berbagai macam tehnik yang dapat digunakan untuk anak. Namun dilihat dari penelitian diatas ada salah satu tehnik yang dapat merugikan anak, maka kita sebagai peneliti harus menyesuaikan tehnik tersebut dengan kondisi dan kemampuan anak dan bagaimana menggunakan tehnik sesuai dengan kenyamanaan anak Hal ini menunjukkan bahwa kemampuan toilet training pada anak down syndrome dapat di tingkatkan melalui pendekatan analisis tugas dengan tehnik modelling.

Penelitian ini diharapkan dapat memberikan pengetahuan kepada orangtua dan guru mengenai manfaat dan pentingnya kemampuan bina diri toilet training, sehingga ketika anak mampu melakukan kegiatan bina diri toilet training, anak dapat mandiri, mampu mengikuti pembelajaran di sekolah, serta dapat dikembangkan ketrampilan bina diri selanjutnya. Disamping itu kegiatan pembelajaran bina diri, khususnya bina diri toilet training ini tidak hanya dapat dilakukan guru disekolah tetapi juga orangtua di rumah, sehingga tujuan pembelajaran yang diinginkan dapat tercapai yakni kemandirian anak down syndrome. 


\section{Kesimpulan}

Berdasarkan Penelitian tentang Pengaruh Toilet training Media Balloon Dengan Tehnik Modelling Terhadap Bina Diri (BAB \& BAK) Anak Down syndrome. Pada kondisi Baseline (A) pengamatan di lakukan selama delapan hari, kemampuan anak di gambarkan grafik menaik dengan keterjalan yang rendah dan cenderung bervariasi sedangkan pada pada kondisi treatment (B) setelah di berikan perlakuan melalui analisis tugas, selama 52 kali pengamatan dalam delapan minggu dengan enam kali pertemuan dalam satu minggu dari hasil ini grafik menaik dengan cukup terjal juga cenderung bervariasi. Berdasarkan hasil pengamatan tersebut maka dapat dapat di simpulkan bahwa adanya peningkatan kemampuan toilet training dalam melakukan buang air kecil anak down syndrome sedang setelah di berikan perlakuan melalui analisis tugas. Maka dapat di simpulkan bahwa analisis tugas dengan tehnik modelling dapat meningkatkan kemampuan toilet training dalam melakukan buang air kecil anak down syndrome SLB Banjarmasin.

Berdasarkan hasil kesimpulan, maka saran yang dapat diberikan oleh peneliti yaitu diantara guru dengan orang tua diharapkan dapat mempertahankan kerjasama dengan ikut berpartisipasi dalam latihan bina diri. Hendaknya guru dan peneliti selanjutnya dapat menerapkan teknik modelling dengan analisis tugas ini dalam mengajarkan bina diri selain untuk meningkatkan keterampilan toilet training. Selain itu, guru juga harus tetap memperhatikan masalah toilet training dan selalu melatih anak down syndrome agar dapat melakukan kegiatan toilet training secara mandiri. Hendaknya orang tua dapat berperan dalam memperhatikan dan membimbing anak dalam latihan bina diri di lingkungan rumah, khususunya pada keterampilan toilet training BAK dan BAB.

\section{Daftar Rujukan}

Affendi, M. (2006). Pengantar Psikopedagogik Anak Berkelainan. Mycological Research.

Andriyani, S., Ibrahim, K., \& Wulandari, S. (2014). Analisis Faktor-Faktor yang berhubungan Toilet Trainingpada Anak Prasekolah. Jurnal Keperawatan Padjadjaran. https://doi.org/10.24198/jkp.v2n3.2.

Andriyani, S., \& Sumartini, S. (2020). Pandangan Orang Tua Tentang Pelaksanaan Toilet Training Berdasarkan Karakteristik Pendidikan Dan Pekerjaan Pada Anak Usia Toodler Di Kota Cimahi. Jurnal Ilmiah Kesehatan Keperawatan, 15(2), 31-42.

Azizah, R.S. (2014). Peningkatan Keterampilan Berbelanja Siswa Tunagrahita Kelas VI Dengan Menggunakan Media Gambar Di SLB Kemala Bhayangkari Trenggalek. Skripsi tidak diterbitkan. Malang: Fakultas Ilmu Pendidikan Universitas Negeri Malang.

Dian Nimas Prameswari, A. L. O. Y. S. I. A., \& Masitoh, S. (2019). Media Tiga Dimensi Terhadap Kemampuan Bina Diri Anak Tunagrahita Ringan. Jurnal Pendidikan Khusus, 11(3).

Eko Suseno, Y. U. D. H. A. (2018). Studi Kasus Pelaksanaan Program Toilet training Anak Multiple Disability with Visual Impairment (MDVI) di SLB-A YPAB Surabaya. Jurnal Pendidikan Khusus, 10(2).

Fernandez, E. (2014). Early childhood: Dimensions and contexts of development and well-being. In Handbook of Child Well-Being: Theories, Methods and Policies in Global Perspective. https://doi.org/10.1007/978-90-481-9063-8_65.

Frima, L. (2013). Gambaran pelaksanaan toilet training pada anak penyandang autisme. Diakses dari http://repository.unri. ac.id:80/handle/123456789/1888.

Hadi, Sutrisno. 1986. Metodologi Research. Yayasan Penerbitan Fakultas Psikologi UGM Jakarta.

Herimanto, W. (2012). Ilmu sosial \& budaya dasar. Jakarta: Bumi Aksara.

Hidayat, Aziz. 2005. Pengantar Ilmu Keperawatan Anak. Jakarta: Salemba Medika.

Hooman, N., Safaii, A., Valavi, E., \& Amini-Alavijeh, Z. (2013). Toilet training in Iranian children: A 
cross-sectional study. Iranian Journal of Pediatrics.

Indrawati, R.D. (2014). Pengembangan Buku Panduan Pengemasan Sayur Organik Bagi siswa Tunagrahita Ringan SMPLB di SLB PTN Bagian C Lawang Malang. Skripsi tidak diterbitkan. Malang: Fakultas Ilmu Pendidikan Universitas Negeri Malang.

Istiqomah, K. (2016). Teknik Modelling Terhadap Kemampuan Toilet training Anak Cerebral Palsy Tklb/D-D1, Jurnal Pendidikan Khusus, 8(2).

Kiddoo, D. A. (2012). Toilet training children: When to start and how to train. In CMAJ. https://doi.org/10.1503/cmaj.110830.

Kustawan, D \& Yanti L. (2014). Program Pengembangan Diri Untuk Peserta Didik Tunagrahita. Jakarta: Direktorat Jendral Pendidikan Dasar Kementerian Pendidikan dan Kebudayaan.

Kusumaningrum, A., Natosba, J., \& Julia, E. L. (2011). Pengaruh pendidikan kesehatan terhadap perilaku orangtua dalam toilet training toddler. Jurnal Ilmu Kesehatan Masyarakat, 2(02), 97102.

Lang, M. E. (2008). Among healthy children, what toilet-training strategy is most effective and prevents fewer adverse events (stool withholding and dysfunctional voiding)?: Part B: Clinical commentary. Paediatrics \& Child Health,13(3), 203.

Maulana, H. (2009). Promosi kesehatan. Jakarta: EGC.

Mariana, A. (2013). Toilet Training pada Anak Down Syndrome. Thesis.

Mrad, F. C. de C., Figueiredo, A. A. de, Bessa, J. de, \& Bastos Netto, J. M. (2018). Prolonged toilet training in children with Down syndrome: a case-control study. Jornal de Pediatria. https://doi.org/10.1016/j.jped.2017.06.011.

Ningsih, S. F. (2015). Hubungan pengetahuan dan perilaku ibu dalam menerapkan toilet training dengan kebiasaan mengompol pada anak usia prasekolah di RW 02 Kelurahan Babakan Kota Tangerang. Diakses dari http://repository.uinjkt.ac.id/dspace/ handle/123456789/25681.

Utami, A. D., \& Galih, F. F. (2019). Bimbingan Kelompok Dengan Teknik Modeling Untuk Meningkatkan Minat Bina Diri Bagi Anak Penyandang Tunagrahita (Studi Kasus Di Slb Langenharjo Sukoharjo) (Doctoral Dissertation, Iain Surakarta).

Panjaitan, R.A., \& Irdamurni, K. (2013). Meningkatkan Kemampuan Toilet training melalui Analisis Tugas pada Anak Tunagrahita Sedang. Jurnal Penelitian Pendidikan Khusus, 2(3).

Powers, M. K., Brown, E. T., Hogan, R. M., Martin, A. D., Ortenberg, J., \& Roth, C. C. (2015). Trends in toilet training and voiding habits among children with down syndrome. Journal of Urology. https://doi.org/10.1016/j.juro.2015.03.114.

Pratiwi, D. A., \& Kustiawan, U. (2017). Pembelajaran Toilet Training bagi Siswa Tunagrahita. Jurnal ORTOPEDAGOGIA. https://doi.org/10.17977/um031v3i22017p091.

Pusparini, W., \& Arifah, S. (2010). Hubungan Pengetahuan Ibu Tentang Toilet training Dengan Perilaku Ibu Dalam Melatih Toilet training Pada Anak Usia Toddler Di Desa Kadokan Sukoharjo.

Putri, N. L. (2014). MODEL PEMBELAJARAN KETERAMPILAN BINA DIRI BAGI ANAK USIA DINI TUNAGRAHITA. PARAMETER: Jurnal Pendidikan Universitas Negeri Jakarta. https://doi.org/10.21009/parameter.252.03.

Rudolph, A. M., \& Hoffman, J. I. E. (2006). Buku ajar pediatri rudolph. Jakarta: EGC. https://doi.org/10.1039/c7ra01024a.

Onen, S., Aksoy, İ., Taşar, M. A., \& Bilge, Y. D. (2012). Factors that affect toilet training in children. Bakırkoy Tip Dergisi, 8(3), 111- 115. 
Trisniati, D. M. (2015). Peningkatan Keterampilan Bina Diri Berakaian dengan Menggunakan Media Model Teman Sekelas untuk Anak Tunagrahita Ringan.

Siregar, Syofian. 2014. Statistik Parametrik untuk Penelitian Kuantitatif Dilengkapi dengan Peritungan Manual dan Aplikasi SPPS Versi 17. Jakarta: PT Bumi Aksara.

Shalahuddin, I., Pebrianti, S., \& Maulana, I. (2018). Hubungan Pengetahuan Dengan Sikap Ibu Dalam Penerapan Toilet training Pada Anak Usia Toddler Di Desa Majasari Garut. Jurnal Publikasi Kesehatan Masyarakat Indonesia, 5(2), 59-64.

Wantah, Maria J (2007). Pengembangan Kemandirian Anak Tunagrahita Mampu Latih. Jakarta: Departemen Pendidikan Nasional Direktorat Jenderal Pendidikan Tinggi. Direktorat Ketenagaan.

Wu, H. Y. (2013). Can evidence-based medicine change toilet-training practice? In Arab Journal of Urology. https://doi.org/10.1016/j.aju.2012.11.001.

Yuwono, I., Kamil, M., Rahardja, D., \& Abdu, W. J. (2017). The effect of guidance and counseling programs on the learning processes of visually impaired high school students. International Journal of Special Education 